\title{
Agnieszka Biedrzycka
}

(D) https://orcid.org/0000-0002-9177-6044

Instytut Historii Polskiej Akademii Nauk im. Tadeusza Manteuffla Polski Słownik Biograficzny

\section{Magda i Mirek Osip-Pokrywka, Polskie ślady na Vkrainie. Przewodnik, BOSZ, wydanie 1, Olszanica 2013, wydanie 1 dodruk, Olszanica 2015, ss. 312}

Recenzowana książka jest kolejną pracą Magdy i Mirka Osip-Pokrywków poświęconą dawnym polskim Kresom południowo-wschodnim ${ }^{1}$. Jak stwierdzili w nazbyt krótkim wstępie autorzy, ich celem było pokazanie krajobrazu „miejsc naznaczonych romantycznym duchem opisów literackich, które wyszły spod pióra Wincentego Pola czy Henryka Sienkiewicza, jak i atmosferą wzniosłych wydarzeń z historii I i II Rzeczypospolitej”, bowiem - jak z nadmiernym pesymizmem uznają - „nie da się już bowiem obecnie z przewodnikową szczegółowością opisać nieistniejącego, a przez to często i niezrozumiałego świata Kresów" (s. 5). Oba te stwierdzenia stanowią ostrzeżenie dla czytelnika, zainteresowanego rzetelnym, obiektywnym i opartym na aktualnym stanie badań przewodnikiem (słowo to znalazło się przecież w tytule książki²), a nie jednostronnym obrazem „wzniosłych wydarzeń” i sugerowanym nim pomijaniem wydarzeń mniej wzniosłych czy wręcz nieprzystających do kresowej

${ }^{1}$ Z podobnej tematyki ukazały się tychże autorów: Sentymentalna Ukraina, Warszawa 2011; Kresy, Warszawa 2013; Leksykon zabytków architektury Kresów południowo-wschodnich, Warszawa 2014.

${ }^{2}$ W odróżnieniu od klasycznych przewodników autorzy nie zamieszczają jednak propozycji szlaków turystycznych, a jedynie opis godnych odwiedzenia miejscowości i obiektów. Praca nie zawiera również przydatnych dla turystów wskazówek praktycznych (chyba że za takie uznamy ostrzeżenie przed standardem usług, sklepów i dróg na Ukrainie), a zamieszczone w niej schematyczne mapy nie mogą stanowić rzeczywistej pomocy w trakcie zwiedzania. 
legendy. Jednocześnie nakreślony w ten sposób cel pracy zdaje się stawiać pod znakiem zapytania sensowność jej omawiania i oceny z punktu widzenia nauki historycznej - recenzentowi trudno oceniać zarówno „romantycznego ducha”, jak „atmosferę wzniosłych wydarzeń”. Skoro jednak autorzy, pisząc o „komplikowaniu” się projektu w miarę realizacji, zastrzegli się, iż „nie wynikało to z braku naszej wiedzy” (s. 5), to również historyk może czuć się upoważniony do sprawdzenia poziomu książki z tego właśnie punktu widzenia. Zwłaszcza że - jak można się spodziewać - jej odbiorcą będzie przede wszystkim nie zawodowy historyk, lecz amator, nie zawsze potrafiący ocenić rzetelność przedstawionych faktów i interpretacji.

W pracy przyjęto topograficzny układ treści, dzieląc Kresy na „Wołyń”, „Ziemię lwowską”, „Karpaty, Pokucie, Bukowinę” oraz „Podole”. W obrębie poszczególnych rozdziałów autorzy zastosowali alfabetyczny układ miejscowości, zaburzony niekiedy dołączonymi do głównych haseł opisami obiektów „Do obejrzenia w okolicy”, co jednak - dzięki zamieszczonemu w pracy indeksowi - nie stanowi utrudnienia dla czytelnika. Można jedynie zastanawiać się, dlaczego autorzy uznali za wskazane dołączenie Berdyczowa do Żytomierza, Podhorzec do Brodów, Dobromila do Sambora, Waręża do Sokala, Rohatyna do Brzeżan czy Czortkowa do Jazłowca, skoro każde z tych miast zasługuje na oddzielny podrozdział, a w niektórych zachowało się więcej „polskich śladów” niż w miejscowościach, do których zostały dołączone.

Więcej wątpliwości budzi sam podział terytorialny. Stosunkowo konsekwentnie potraktowano Wołyń, w którym znalazły się niemal wyłącznie miejscowości należące do województwa wołyńskiego z czasów I Rzeczypospolitej (chociaż dołączono tu także Luboml i Maciejów z ziemi chełmskiej woj. ruskiego oraz Żytomierz z woj. kijowskiego). Znacznie trudniej zrozumieć określenie „Ziemia lwowska”. W opatrzonym tym tytułem rozdziale umieszczono zarówno miejscowości należące do historycznej ziemi lwowskiej, jak i stanowiący stolicę osobnego województwa Bełz oraz leżący w województwie bełskim Krystynopol, a także należące do ziemi przemyskiej Drohobycz i Sambor. Całkowicie ahistoryczny jest zbiór miejscowości w rozdziale „Karpaty, Pokucie, Bukowina”, obejmującym miejscowości nigdy niestanowiące części Rzeczypospolitej (Chocim, Czerniowce) oraz należące niegdyś do województwa podolskiego (Okopy) i ziemi halickiej województwa ruskiego (Czernelica, Kołomyja, Kosów, Kuty, Stanisławów). Podobnie rozdział „Podole” obok obiektów rzeczywiście podolskich (Bar, Borszczów, Husiatyn, Jazłowiec, Kamieniec Podolski, Latyczów, Międzybóż, Sidorów, Skała nad Zbruczem) zawiera miejscowości należące do ziemi lwowskiej (Brzeżany) i halickiej (Buczacz, Czortków, Halicz, Kałusz, Liczkowce, Mikulińce, Podzameczek, Rohatyn, Tarnopol, Trembowla) oraz województwa wołyńskiego (Zbaraż, dołączony w dodatku do Tarnopola) i bracławskiego (Bracław, Humań, Tulczyn, Winnica). Tego typu dowolność nie przynosi autorom i czytelnikowi żadnych korzyści, zaciera natomiast istniejące przez kilkaset lat i ważne dla historii tych ziem podziały administracyjne.

W wielu przypadkach trudno zrozumieć dokonany przez autorów wybór opisanych miejscowości i zabytków. Dlaczego pominięto np. Bołszowce, Hodowicę, Jagielnicę, Obroszyn, Podhajce, Podkamień, Sławutę, Stryj czy Szarogród? Większość 
tych miast została uwzględniona w przygotowanym zapewne w tym samym czasie Leksykonie zabytków architektury, a zatem przyczyną pominięcia nie był brak informacji czy niewiedza. Podobnie zaskakujące bywa opuszczenie niektórych obiektów znajdujących się w granicach opisanych miejscowości. Szczególnie pobieżnie opracowano część poświęconą Lwowowi, a wybór kilku opisanych w niej obiektów wydaje się czysto przypadkowy (m.in. spośród lwowskich świątyń uwzględniono w zasadzie tylko katedry, a spośród kilkudziesięciu kamienic przy Rynku zaledwie trzy). Karykaturalnie przedstawiono historię miasta, mieszczącą się na niespełna czterech stronach i obejmującą rozważania autorów na temat jego początków (o czym dalej), oblężenie przez Bohdana Chmielnickiego jesienią 1648 r. i stan na początku XX w. Zgadzając się z autorami, że „Nie sposób opisać tutaj wszystkich zabytków miasta” (s. 120), nie sposób też uznać za wystarczające podane przez nich strzępy informacji. Jeszcze trudniej zrozumieć zasady selekcji w przypadku mniejszych miast (zarówno uwzględnionych przez autorów, jak i całkowicie zignorowanych), zawierających jedynie nieliczne „polskie ślady”. Do takich pominiętych obiektów można zaliczyć np. polskie tablice pamiątkowe (m.in. Tadeusza Kościuszki w Kołomyi i Mościskach, Zygmunta Krasińskiego w Kołomyi i Monasterzyskach, Adama Mickiewicza w Grzymałowie, Henryka Sienkiewicza w Kamionce Strumiłłowej, Monasterzyskach i Mościskach, Juliusza Słowackiego w Monasterzyskach, Jana III Sobieskiego w Czortkowie, Otyni, Samborze i Stryju, Konstytucji Trzeciego Maja w Czortkowie i Rohatynie, bitwy grunwaldzkiej w Otyni i Szczercu, odzyskania Niepodległości w Budzanowie), pomniki Adama Mickiewicza w Kołomyi i Podhajcach, zespoły epitafiów w Berdyczowie, Białej Cerkwi, Biłce Szlacheckiej, Chomiakówce, Dunajowie, Dźwiniaczce, Kopyczyńcach, Kulikowie, Mołczanach, Nowym Mieście, Obroszynie, Podhorcach, Rozdole, Sławucie i wiele innych obiektów. Po raz kolejny dobór wydaje się dziełem przypadku. Dlaczego autorzy uznali za godną upamiętnienia banalną, dwudziestowieczną inskrypcję dewocyjną ze Świętego Stanisława (s. 246), a nie poświęcili żadnej uwagi dziesiątkom podobnych (a często znacznie bardziej interesujących) napisów z Bóbrki, Budzanowa, Dawidowa, Czernielowa Mazowieckiego, Hałuszczyniec, Jaworowa, Kłodna, Kochawiny, Litowyszcza, Łukowca Wiszniowskiego, Milatyna Nowego, Sambora, Słobódki Janowskiej, Strzałkowic, Tucznej i innych miejscowości? ${ }^{3}$ Opisując kościół farny w Drohobyczu, autorzy stwierdzili, iż z dawnego wyposażenia „zachowało się jedynie kilka rzeźb z ołtarzy oraz fragment płaskorzeźby” (s. 97), nie zauważając kilkumetrowej wysokości drewnianych tablic z końca XVIII w. z łacińskimi opisami historii kościoła ${ }^{4}$. W katedrze w Żytomierzu odnotowali „liczne epitafia biskupów, tablicę poświęconą kompozytorowi Juliuszowi Zarębskiemu i poległym mieszkańcom Żytomierszczyzny" (s. 78), pominęli natomiast najstarsze epitafium burgrabiego radomskiego Józefa Trzeciaka z 1750 r. Podobne przykłady można mnożyć. Skoro jako cel

${ }^{3}$ Większość wymienionych inskrypcji zamieszczono w serii Pomniki epigrafiki i heraldyki dawnej Rzeczypospolitej na Ukrainie, red. W. Drelicharz, t. 1: Ziemia lwowska dawnego województwa ruskiego, oprac. A. Biedrzycka, Kraków 2005; t. 2: Dawne województwo podolskie, oprac. P. Kuliszewicz, Kraków 2005; t. 3: Ziemia przemyska dawnego województwa ruskiego, oprac. A. Marzec, Kraków 2008.

${ }^{4}$ Zob. Pomniki epigrafiki..., t. 3, s. 76-82. 
wydawnictwa określono zapoznanie czytelnika $\mathrm{z}$ „polskimi śladami na Ukrainie”, to należało więcej uwagi poświęcić tym właśnie śladom, zamiast rejestrować dziewiętnastowieczne prawosławne cerkwie (np. s. 15, 17, 67, 183), współczesne ukraińskie pomniki (s. 12, 200) czy katedrę ormiańską i pałac prawosławnych metropolitów bukowińskich w Czerniowcach (s. 193-194)5. Trudno żądać uwzględnienia wszystkich zachowanych na Ukrainie „polskich śladów”, jednak stwierdzając, że „W wielu miejscach jedynymi świadkami polskiej bytności na tych ziemiach są tylko krzyże na cmentarzach czy resztki kościelnych murów, które wkrótce znikną w gęstwinie traw i dzikich krzewów" (s. 5), autorzy nie mieli chyba na myśli lwowskiej katedry św. Jura?

Opis historii poszczególnych miejscowości autorzy oparli, zdaje się, głównie na przewodnikach Grzegorza Rąkowskiego, dokonując jednak niekiedy karkołomnych skrótów. Przykładowo w opisie Oleska z podanej przez Rąkowskiego informacji „W 1327 r. Oleskiem władał książę halicko-wołyński i mazowiecki z rodu Piastów, Bolesław-Jerzy Trojdenowicz” autorzy pozostawili „W 1327 r. Oleskiem władał książę halicko-wołyński i mazowiecki” (s. 138), z nieznanych przyczyn ukrywając jego imię. W wyniku zbyt daleko idących skrótów (i zaskakującej interpunkcji) zupełnie nieczytelny stał się fragment dotyczący dalszych dziejów Oleska: „Na początku XVII w. miasto znalazło się w rękach kasztelana lwowskiego Jana Daniłowicza, ożenionego z córką Stanisława Żółkiewskiego, Zofią. Murowany zamek oleski, który przetrwał w mniej czy bardziej zmienionej postaci do naszych czasów, był dziełem właśnie Jana Daniłowicza, a wzniesiono go na miejscu starej, drewnianej warowni. Po śmierci syna, Stanisława, Jana, jedna z trzech córek, Zofia Teofila, odziedziczyła Żółkiew i wyszła za mąż za Jakuba Sobieskiego. Odwiedzała często swoje siostry, które wspólnie otrzymały w spadku Olesko, i podczas jednej z dłuższych wizyt, w 1629 r. właśnie tutaj urodziła Jana, późniejszego króla Polski” (s. 138). Konia z rzędem temu, kto na podstawie tego fragmentu zrozumie, kim właściwie byli Jan i Stanisław, a czyją córką była Zofia Teofila. Wydawałoby się również, że opisując historię Oleska, należałoby podać raczej imiona władających nim sióstr (Marcjanny Koniecpolskiej i Katarzyny Firlejowej), a nie właścicielki Żółkwi.

Niemal wszystkie opisywane obiekty autorzy znają z autopsji, jedynie w nielicznych wypadkach można mieć wrażenie pokładania przez nich zbytniej ufności we wcześniejsze opracowania. Tak jest zapewne w przypadku tablicy pamiątkowej z 1778 r., która rzekomo zachowała się w dawnym kościele dominikańskim w Tarnopolu (s. 282). Wiadomość tę zasięgnięto prawdopodobnie z przewodnika Rąkowskiego, nie sprawdzając jej wiarygodności. O zapożyczeniu z tej właśnie pracy świadczy podobny sposób przekazania informacji i brak bliższych szczegółów na temat lokalizacji tablicy: „Na jednej ze ścian znajduje się tablica pamiątkowa z 1778 r. poświęcona

\footnotetext{
${ }^{5}$ Jedynie wspomniano natomiast synagogę reformowaną, mogącą akurat uchodzić za „polski ślad” w Czerniowcach dzięki osobie swego twórcy, profesora i rektora lwowskiej Szkoły Politechnicznej Juliana Zachariewicza, którego nazwiska nawet nie wymieniono (por. Ю. Бірюльов, Захаревичі. Твориі столичного Львова, Львів 2010).

${ }^{6}$ G. Rąkowski, Przewodnik po Ukrainie Zachodniej, cz. 3: Ziemia lwowska, Pruszków 2007, s. 303.
} 
fundatorowi świątyni i klasztoru, Józefowi Potockiemu” (Rąkowski) ${ }^{7}$, „Na jednej ze ścian zachowała się pamiątkowa tablica z 1778 r., którą dominikanie poświęcili fundatorowi klasztoru, Józefowi Potockiemu" (Osip-Pokrywko; toż w Leksykonie i Sentymentalnej Ukrainie). W rzeczywistości chodzi o nieistniejące obecnie drewniane epitafium Potockiego, znajdujące się pierwotnie na pilastrze w południowej części nawy głównej, znane z odpisu Władysława Żyły ${ }^{8}$. Ze zbytniej wiary w niesprawdzone informacje literatury wynika również stwierdzenie, iż nad portalem kościoła w Buczaczu „dostrzec można kartusz z herbem Pilawa” (s. 240), i to mimo zamieszczonych obok fotografii (s. 239 i 240), na których nad portalem dostrzec można wyłącznie inskrypcję i puste miejsce po kartuszu?.

Autorzy ze zdumiewającą naiwnością uznali, że po wkroczeniu do Stanisławowa Armii Czerwonej „W Ukraińcach i wspierających ich Żydach obudziły się nastroje nacjonalistyczne, Sowietów przyjęto z radością, Polaków nagle znienawidzono" (s. 224). Czy naprawdę nastroje nacjonalistyczne i nienawiść do Polaków obudziły się w Ukraińcach dopiero we wrześniu 1939 r.? Z czego zatem wynikała wojna polsko-ukraińska 1918-1919 oraz późniejsza działalność Ukraińskiej Organizacji Wojskowej i Organizacji Ukraińskich Nacjonalistów? Kto i po co przeprowadził zamachy na Stanisława Wojciechowskiego, Józefa Piłsudskiego, Stanisława Sobińskiego, Emila Czechowskiego, Tadeusza Hołówkę i Bronisława Pierackiego? Przeciw komu polskie wojsko i policja przeprowadziły pacyfikację Małopolski Wschodniej we wrześniu 1930 r.? Za co zastrzelono Juliana Hołowinskiego, powieszono Wasyla Biłasa i Dmytra Danyłyszyna, skazano na siedmiokrotne dożywocie Stepana Banderę? Czy rzeczywiście Ukraińcy (a zwłaszcza ukraińscy nacjonaliści), zdający sobie przecież sprawę z sytuacji na Ukrainie Naddnieprzańskiej, witali Armię Czerwoną „z radością”? Jakie nastroje „nacjonalistyczne” obudziły się na widok Armii Czerwonej w Żydach (bo chyba jednak nie ukraińskie)? Ta sama naiwność widoczna jest również w wierze w panującą na Kresach sielankę „zgody i braterstwa” (s. 224), przerwaną rzekomo agresją sowiecką.

Praca nie jest wolna od błędów merytorycznych. W bitwie pod Beresteczkiem nie brała udziału „armia konna” (s. 8), gdyż taka formacja w wojskach Rzeczypospolitej Obojga Narodów nie istniała, lecz armia koronna, w której szeregach znalazło się również kilka tysięcy piechoty. Ordynat Ferdynand Radziwiłł nie mógł zatrudnić

7 Idem, Przewodnik po Ukrainie Zachodniej, cz. 2: Podole, Pruszków 2006, s. 138.

8 W. Żyła, Kościót OO. Dominikanów w Tarnopolu 1749-1779, Lwów 1917, s. 73-74. Odpis (za W. Żyłą) przytoczono również w najnowszym opracowaniu na temat kościoła Dominikanów, zob. J. Skrabski, Kościót p.w. św. Wincentego Ferreriusza i klasztor oo. Dominikanów z przynależnymi zabudowaniami w Tarnopolu, [w:] Materiały do dziejów sztuki sakralnej na ziemiach wschodnich dawnej Rzeczypospolitej, cz. 1: Kościoly i klasztory rzymskokatolickie dawnego województwa ruskiego, t. 16, red. J. K. Ostrowski, Kraków 2008, s. 287-288 (epitafium oznaczone jako zniszczone lub zaginione).

${ }_{9}$ Informacje o rzekomo zachowanym herbie na fasadzie kościoła w Buczaczu funkcjonuje powszechnie w literaturze kresowej, zob. np. G. Rąkowski, Przewodnik..., cz. 2, s. 266; A. Smoliński, „Bez ognia i miecza”. Migawki z sentymentalnych podróży po niepodległej Ukrainie w poszukiwaniu śladów byłej Rzeczypospolitej Obojga Narodów, „Semper Fidelis” 2008, nr 5, s. 6; J. Czarnowski, Perty Kresów, Warszawa 2010, s. 75; A. Strojny, K. B zowski, A. Grossman, Ukraina zachodnia. Tam szum Prutu, Czeremoszu..., Kraków 2011, s. 375. 
budowniczego teatru miejskiego we Lwowie Zygmunta Gorgolewskiego na zamku w Ołyce w 1914 r. (s. 59), skoro Gorgolewski zmarł 5 lipca 1903 r. ${ }^{10}$ Niezrozumiała jest informacja o dokończeniu budowy kościoła katolickiego pw. Narodzenia NMP i św. Antoniego w Równem pod koniec XIX w., „gdy przestał obowiązywać carski zakaz wznoszenia wolnostojących świątyń staroobrzędowych” (s. 66). Czyżby kościół ten został wybudowany jako świątynia staroobrzędowców? Włodzimierz nie był stolicą województwa wołyńskiego (s. 72), a jedynie jednego z jego powiatów; nieporozumieniem wydaje się również „XV-wieczny pałac biskupów unickich” (s. 73) w tym mieście, skoro powstanie Kościoła unickiego datujemy od 1596 r. Żytomierza nie włączono do województwa kijowskiego w 1569 r., „po zawarciu Unii Lubelskiej” (s. 76), a jedynie razem $\mathrm{z}$ niemal całym województwem ${ }^{11}$ przyłączono do Korony (w dodatku nie po, a przed zawarciem unii). Spośród dwóch podanych dat chrztu królewicza Aleksandra Sobieskiego: 1678 (s. 100) i 1687 (s. 101) prawdziwa jest ta pierwsza. Nad portalem kościoła w Komarnie nie „pozostało miejsce po tablicy erekcyjnej” (s. 106), lecz cała, choć słabo czytelna tablica ${ }^{12}$.

W podrozdziale dotyczącym Lwowa autorzy zaskakują czytelnika stwierdzeniem, iż „wiele wskazuje na to, że początki miasta wcale nie sięgają połowy XIII w., a czasów znacznie wcześniejszych" (s. 117). Zaskakujące jest nie samo stwierdzenie, bo o tym, że przyjmowany jako „początek Lwowa” rok 1256 nie jest rokiem powstania miasta, wiadomo od dawna; jest to jedynie data wymieniona w pierwszej znanej pisemnej wzmiance o Lwowie. Zaskakuje natomiast zdumienie autorów powszechnie znanymi faktami. Ślady osadnictwa na terenie miasta sięgają zresztą czasów znacznie dawniejszych niż wspomniane przez autorów. Badania ratownicze, przeprowadzone w 1992 r. w wykopach pod fundamenty hotelu „Zołotyj Łew”, które wykazały pozostałości archeologiczne należące do tzw. kultury praskiej, świadczą o stałym zasiedleniu doliny Pełtwi już ok. V-VII w. n.e. ${ }^{13}$, a pierwsze ślady obecności na tym terenie ludzi datuje się na późny paleolit (ok. 27 tys. lat temu) ${ }^{14}$. Nie jest prawdą, jakoby fakty te nie zostały uwzględnione w pracach polskich badaczy (s. 118), o czym autorzy doskonale wiedzą, bowiem poświęcony temu zagadnieniu tekst (łącznie z przytoczonymi fragmentami wcześniejszych opracowań Antoniego Schneidra i Ignacego Drexlera) zaczerpnęli z jednego $\mathrm{z}$ artykułów Łukasza Walczego o początkach Lwowa ${ }^{15}$, z powo-

${ }^{10}$ S. Łoza, Gorgolewski Zygmunt, [w:] Polski słownik biograficzny, t. 8, Wrocław-Warszawa-Kraków 1959-1960, s. 316.

${ }^{11}$ Do Korony nie przyłączono jedynie powiatu mozyrskiego, który na żądanie miejscowej szlachty pozostał przy Litwie i został włączony do województwa mińskiego (Urzędnicy województw kijowskiego i czernihowskiego XV-XVIII wieku. Spisy, oprac. E. Ja nas i W. Kłaczewski, Kórnik 2002, s. 6).

${ }_{12}$ Zob. Pomniki epigrafiki..., t. 1, s. 184-185.

13 В. Петегирич, Найдавніше слов'янське житло зі Львова, „Галицька брама” 1996, nr 12, s. 3 .

${ }^{14}$ Id em, Bстуn, [w:] Історія Львова, red. Я. Ісає в ич, т. 1: 1256-1772, Львів 2006, s. 30-31.

${ }^{15}$ Ł. Walczy, Dzieje wielkiego błędu. Ewolucja poglądów na początki Lwowa, „Cracovia-Leopolis” 2001, nr 1, s. 6. Autor przedstawiał swą koncepcję kilkakrotnie, zob. też: id em, Początki Lwowa w świetle najnowszych badań, „Sprawozdania z Posiedzeń Komisji Naukowej PAN. Oddział w Krakowie” 1998, t. 42/1, s. 138-143; idem, W sprawie początków Lwowa, [w:] Lwów. Miasto, społeczeństwo, kultura, t. 4, red. K. Karolczak, Kraków 2002, s. 31-37; id em, Początki Lwowa w świetle najnowszych badań, „Cracovia-Leopolis” 2004, nr 2, s. 8-11. Ciekawe, że swoje „odkrycie” autorzy zamieścili w dwóch edycjach 
łaniem się na te same publikacje i powieleniem błędów w transkrypcji ukraińskich tytułów: „Jest pożałowania godnym paradoksem, że potwierdzenie faktu istnienia osadnictwa we Lwowie wstecz do X wieku, a nawet do czasów wcześniejszych, znajdujemy nie gdzie indziej, jak w pracach uczonych ukraińskich, stworzonych w epoce sowieckiej. Ze strony polskiej zadawnione błędy wciąż oczekują na sprostowanie, sam zaś Lwów czeka na to, aby mieć wreszcie swoją najdawniejszą historię napisaną rzetelnie i po polsku” (Walczy); „już jako paradoks jawi się, że potwierdzenie faktu istnienia osadnictwa we Lwowie w X w., a nawet wcześniej, znaleźć można w opracowaniach nie polskich, a ukraińskich naukowców. Dzieje Lwowa powinny doczekać się poważnego opracowania historycznego" (Osip-Pokrywko). Autorzy nie zadali sobie trudu skonfrontowania wspomnianych przez Walczego prac z oryginałami, skoro np. o cytowanym przezeń artykule Aleksandra Czołowskiego wspominają dwukrotnie prawidłowo jako o „szkicu historycznym zamieszczonym w monumentalnym wydawnictwie z 1896 r. Miasto Lwów w okresie samorządu” (s. 118; Walczy pisze o „szkicu historycznym Czołowskiego, zamieszczonym w monumentalnym wydawnictwie z r. 1896: Miasto Lwów w okresie samorzadu) oraz błędnie: „Aleksander Czołowski w swej pracy z 1865 [!] r. Obrazy dziejowe Lwowa (zamieszczonej w dziele zbiorowym Miasto Lwów w okresie samorządu 1870-1895, wydanym we Lwowie w 1896)" (s. 119).

Nie lepiej wygląda dalsza część rozdziału poświęconego stolicy Galicji: Lwów nie był na początku XX w. siedzibą „najwyższych władz państwowych” (s. 120), bo te rezydowały w Wiedniu, lecz władz krajowych, czyli galicyjskich. Władysław Jagiełło przyjmował na Rynku hołd nie od wojewody wołoskiego Aleksandra (s. 120), lecz wojewody mołdawskiego Piotra. Wały Hetmańskie zawdzięczały swą nazwę nie „dwóm pomnikom sławnych hetmanów - wielkiego koronnego Stanisława Jabłonowskiego, broniącego Lwowa przed Tatarami, oraz króla Jana Sobieskiego" (s. 124), a jedynie pomnikowi Jabłonowskiego; monument Sobieskiego powstał wiele lat po nadaniu wałom miana Hetmańskich. W trzech lwowskich katedrach rezydowali biskupi (a nawet arcybiskupi) nie „trzech różnych wyznań” (s. 128), lecz trzech różnych obrządków tego samego wyznania - katolickiego. Kościół rzymskokatolicki na Łyczakowie nosi wezwanie nie św. Jerzego (s. 129), lecz św. Antoniego Padewskiego. Iwan Franko został patronem uniwersytetu lwowskiego nie po wojnie (s. 135), lecz już 8 stycznia 1940 r. ${ }^{16}$ Liczba 2589 pochowanych na cmentarzu Obrońców Lwowa to nie liczba poległych obrońców ${ }^{17}$ (s. 136), tylko wszystkich pogrzebanych tam uczestników walk, w ogromnej większości zmarłych po ich zakończeniu ${ }^{18}$.

Polskich śladów z roku 2013 (pierwodruk) i 2015 (dodruk), natomiast całkowicie pominęli w Leksykonie zabytków z roku 2014, gdzie zgodnie z krytykowanym przez siebie poglądem stwierdzili: „Lwów został założony ok. 1250 przez księcia Daniela I Halickiego" (s. 228).

${ }^{16}$ G. Mazur, J. Skwara, J. Węgierski, Kronika 2350 dni wojny i okupacji Lwowa 1 IX 1939 - 5 II 1946, Katowice 2007, s. 106.

${ }_{17} \mathrm{~W}$ trakcie walk we Lwowie od 1 do 22 XI 1918 r. zginęło lub zmarło z ran 439 żołnierzy i członków wojskowej służby sanitarnej (M. Klimecki, Wojna polsko-ukraińska. Lwów i Galicja Wschodnia 1918-1919, Warszawa 2000, s. 140).

${ }_{18}$ Ostatni zmarły przed wybuchem II wojny obrońca Lwowa, Władysław Preisner, został pochowany na Cmentarzu Orląt 9 VIII 1939 r. (S. S. Nicieja, Cmentarz Obrońców Lwowa, Wrocław-Warszawa-Kraków 1990, s. 117). 
Seweryn Rzewuski, syn Wacława i rzekomo „zarazem ostatni z rodu Rzewuskich” (s. 140), który sprzedał Olesko Aleksandrowi Zielińskiemu, to w rzeczywistości hetman polny koronny (ojciec m.in. Wacława Seweryna zwanego Emirem), najwyraźniej pomylony ze zmarłym bezpotomnie w 1754 r. stryjem, wojewodą wołyńskim Sewerynem. Po bezpotomnym wojewodzie Sewerynie Olesko przejął jego brat, hetman wielki koronny Wacław, a po nim zamek odziedziczył wspomniany już hetman Seweryn i to on dopiero sprzedał go w 1796 r. Zielińskiemu. Określenie Gabriela Świrskiego jako „znanego humanisty” (s. 165) wydaje się mocno przesadzone; jedynym znanym efektem jego działalności na polu kultury jest przekład Georgik Wergiliusza, z którego zachowała się tylko jedna księga, w dodatku aż do XX w. pozostająca w rękopisie ${ }^{19}$. Nie jest znana również data jego śmierci (według autorów zmarł on w 1610 r.) - ostatnie wzmianki źródłowe o Świrskim pochodzą z 1588 r., dalsze jego losy pozostają nieznane. Zachowana w zrujnowanym kościele podominikańskim w Czernelicy Pilawa nie jest „herbem Potockich” (dwukrotnie na s. 187), lecz Stanisławskich. Autorzy o tym wiedzą, z dziwną logiką stwierdzają jednak: „Jest również ciekawostka: na lewo, przy ogołoconej wnęce ołtarzowej, nad wejściem do zakrystii wisi kamienna tablica $\mathrm{z}$ herbem Potockich - Pilawa. Nie jest to przypadek. Fundatorem kościoła był wprawdzie książę Michał Czartoryski z Klewania, ale litery umieszczone wokół herbu: «E. S., X. C., W. W.», niezbicie potwierdzają, że przyczyniła się do tego również jego żona: Eufrozyna Stanisławska, Xiężna Czartoryska, Wojewodzina Wołyńska”. Nie sposób zrozumieć, dlaczego inskrypcja upamiętniająca Stanisławską miałaby świadczyć o celowości zamieszczenia w jej sąsiedztwie herbu Potockich. Łuka nie jest historycznym miejscem przeprawy przez Dniestr „króla Jana Sobieskiego idącego na Wiedeń" (s. 189), lecz hetmana Jana Sobieskiego idącego na Chocim. Sobieski nie włączył Czerniowiec do Rzeczypospolitej (s. 192), a jedynie osadził w nich polski garnizon. Józef Korzeniowski nie napisał pieśni Czerwony pas (s. 198), lecz Czerwony płaszcz, śpiewaną później ze zmienionymi słowami.

Książę Lubart nie był Koriatowiczem (s. 230), lecz Giedyminowiczem. Zygmunt August towarzyszył konduktowi żałobnemu zmarłego w czasie obrad sejmu lubelskiego Mikołaja Sieniawskiego nie „do samych Brzeżan” (s. 232), a jedynie poza mury Lublina. Figura św. Jana Nepomucena w Buczaczu została odtworzona nie w roku 2000 (s. 239), lecz 2007, jak o tym świadczy napis na jej cokole ${ }^{20}$. W opisie legendy dotyczącej powstania nazwy Jezupol autorzy połączyli dwie jej wersje, w dodatku błędnie przypisując założenie miasta hetmanowi Stanisławowi Janowi Jabłonowskiemu (s. 245), który, urodzony w 1634 r., nie mógł nadać nazwy Jezupolowi, znanemu pod nią już na początku XVII w. Szczęsny Potocki nie żył w Humaniu „w spokoju aż do 1834 r." (s. 248), ponieważ zmarł w roku 1805 (prawidłową datę autorzy podają na s. 291 i 292). Tymon Zaborowski (a nie Zborowski, jak konsekwentnie autorzy piszą na s. 257) nie był poetą renesansu, lecz klasycyzmu i romantyzmu. Bitwa nad Sinymi

${ }^{19}$ S. Seliga, Pasiecznik. Parafraza IV. ks. Georgik Wergilego dokonana przez Gabrjela Świrskiego (w wieku XVI), „Prace Filologiczne” 1928, t. 9, s. 244-277.

${ }_{20}$ Zob. W. Szklarz, Pomnikśw. Jana Nepomucena obok drogi Buczacz-Podzameczek, „Głos Buczaczan” R. 17, 2008, nr 2, s. 47. 
Wodami miała miejsce nie w 1352 r. (s. 265), lecz w 1362 r. Cerkiew w Tarnopolu nie mogła być ufundowana ,jeszcze przez wojewodę kijowskiego Tomasza Zamoyskiego pod koniec XVI w." (s. 282), skoro Zamoyski, urodzony w 1594 r., wojewodą został dopiero 25 lat później, a przy pochodzącej z końca XVI w. cerkwi jedynie wystawił w 1627 r. murowaną wieżę. Pomnik Anny Doroty Chrzanowskiej autorstwa Jana Bochenka nie powstał w stulecie oblężenia Trembowli (s. 286). Wprawdzie pierwszy pomnik wystawiono Chrzanowskiej już pod koniec XVIII w., uległ on jednak zniszczeniu ok. 1829 r. Wobec zbliżającej się dwusetnej rocznicy oblężenia rada miejska Trembowli podjęła 20 marca 1869 r. decyzję o budowie nowego pomnika i przeznaczyła na ten cel 300 złotych reńskich, zamierzając zebrać brakującą kwotę drogą zbiórki publicznej. Rozpoczęto ją w 1875 r., jednak apel o składki nie dał spodziewanego efektu i w $1876 \mathrm{r}$. z budowy zrezygnowano, a zebrane środki postanowiono przeznaczyć na rozbudowę gmachu szkoły „i zaopatrzenie takowego w tablicę pamiątkową ze stosownym napisem"21 (ostatecznie pieniądze wpłacono do banku, odkładając budowę pomnika do czasu przyrostu oprocentowania zebranej sumy). Do projektu powrócono w związku z obchodami dwusetnej rocznicy odsieczy wiedeńskiej i w $1886 \mathrm{r}$. wzniesiono w parku miejskim pomnik według projektu Tadeusza Barącza, przedstawiający obelisk zwieńczony rzeźbą orła z rozpostartymi skrzydła$\mathrm{mi}$, trzymającego w szponach wieniec laurowy (pomnik ten, pozbawiony orła, istniał jeszcze w roku 1972) ${ }^{22}$. Dopiero w ostatnich latach XIX w. przypomniano projekt pomnika z figurą Chrzanowskiej, który wykonano według projektu Jana Bochenka ${ }^{23}$ i odsłonięto w listopadzie $1900 \mathrm{r}^{24}$ Nie został on "ostatecznie zniszczony w 1944 r.” (s. 286), bowiem figura, uszkodzona już przed 17 maja $1943 \mathrm{r}^{25}$, po 1944 r. została zrzucona $\mathrm{z}$ cokołu, przetrwała jednak w Trembowli co najmniej do roku 1972, po czym została podobno uznana za zabytek i przeniesiona do muzeum w Kijowie ${ }^{26}$. Wydaje się, że autorzy błędnie zidentyfikowali tablicę pamiątkową Franciszka Żwirki i Stanisława Wigury, stwierdzając, że „latem 2010 r. po tablicy był już tylko ślad wykucia jej z muru, zamalowany graffiti” (s. 286); prawdopodobnie za miejsce po tej tablicy uznali zachowane w murze ozdobne obramienie ( $\mathrm{z}$ wieńcem $\mathrm{z}$ liści dębowych i laurowych, płaskorzeźbionym orłem oraz podłożoną szablą i buławą) innej płyty, nieistniejącej już na początku lat $90 . \mathrm{XX} \mathrm{w.}^{27}$

${ }^{21}$ Wiadomości społeczne, „Przegląd Tygodniowy Życia Społecznego, Literatury i Sztuk Pięknych” R. 11, 1876, nr 23, s. 276.

${ }^{22}$ Fot. zob.: A. J. Bayger, Powiat trembowelski, Lwów 1899, s. 310; W. Szetelnicki, Trembowla. Kresowy bastion wiary i polskości, Wrocław 1992, s. 26-28.

${ }^{23}$ Według Jurija Biriulowa mógł on wykonać pomnik na podstawie modelu przygotowanego w 1877 r. przez lwowskiego rzeźbiarza Leonarda Marconiego (J. Biriulow, Rzeźba lwowska od połowy XVIII wieku do 1939 roku, Warszawa 2007, s. 157).

${ }^{24}$ Pomnik Chrzanowskiej, „Kurier Lwowski” R. 18, 1900, nr 317, s. 1.

${ }^{25}$ Wieści z powiatów. Przeszłość i piękno Trembowli, „Gazeta Lwowska” R. 3, 1943, nr 114, s. 3.

${ }^{26}$ W. Szetelnicki, op. cit., s. 26.

${ }^{27} \mathrm{Z}$ pewnością też tablicy nie usunęli „bezduszni wandale chcący zarobić parę hrywien na sprzedaży złomu", jak przypuszczali autorzy w Sentymentalnej Ukrainie (s. 98), gdyż podobnie jak kilkanaście innych, zignorowanych przez nich tablic pamiątkowych na murze zamku została ona wykonana $\mathrm{z}$ piaskowca. 
Województwo bracławskie nie zostało utworzone na sejmie w Lublinie (s. 294), lecz na sejmie litewskim w Wilnie, a po unii lubelskiej nie stało się „najdalej na południowy wschód wysuniętą częścią I Rzeczypospolitej” (s. 294), gdyż kilkaset kilometrów dalej na południowy wschód sięgało województwo kijowskie. Nie wiadomo, skąd autorzy zaczerpnęli informacje o powierzchni województwa bracławskiego (32 tys. $\mathrm{km}^{2}$, s. 294); według Historii Polski w liczbach ${ }^{28}$ jego przybliżona powierzchnia (dokładne dane nie istnieją) wynosiła 59,5 tys. $\mathrm{km}^{2}$. Leon Antoni Brunicki gościł w 1852 r. w Zaleszczykach nie cesarza Franciszka II (s. 301), lecz Franciszka Józefa.

W tekście zdarzają się błędy w pisowni nazw własnych: Prośla (s. 25) zamiast Porośla, Lubomil (s. 41-42, tak też w indeksie) i Lubmil (mapa na s. 6) zamiast Luboml, Kodyna i Berszad (mapa na s. 227) zamiast Kodnia i Berszada, Kampinos (s. 105) zamiast Kapinos, Lonfessor (s. 151) zamiast Confessor. Na s. 47 zamieniono podpisy obok fotografii. Zaznaczony na mapie "Ziemi lwowskiej” Rakowiec (s. 83, między Wiśniowcem i Zbarażem) z pewnością nie jest Rakowcem nad Dniestrem, opisanym na s. 189, chociaż rzeczywiście między Wiśniowcem i Zbarażem znajduje się miejscowość o tej samej nazwie. Podobnie umieszczony na mapie „Karpat, Pokucia, Bukowiny" Czerwonogród (s. 182, na południowy wschód od Iwano-Frankiwska) poza nazwą nie ma nic wspólnego z opisaną na s. 304-305 miejscowością.

Książka Polskie ślady na Ukrainie rozczarowuje. Jest pracą pobieżną, nieprzemyślaną, kompilatorską i obfitującą w błędy. Wydawałoby się, że w ćwierć wieku po rozpoczęciu kresowego boomu wydawniczego takie prace nie mają racji bytu. Niestety, bazująca na Kresach bylejakość najwyraźniej ma się świetnie (praca doczekała się dodruku), a ironiczna „recepta na relację z Kresów” Janusza Tazbira pozostaje w użytku: „trzeba wziąć auto i objechać małe miejscowości, znane z historii lub literatury pięknej (najlepiej takie, o których wspominał Henryk Sienkiewicz). Prawie w każdej z nich znajdzie się kościół dźwigany z ruin, przy pomocy ofiarnego księdza i jakże nielicznych parafian. $Z$ ich to ust słyszymy opowieść o prześladowaniach, $\mathrm{z}$ jakimi się oni oraz ich wyznanie spotykali i zapewnienie, że wszystko idzie ku lepszemu. Drugą część relacji stanowią zazwyczaj informacje zaczerpnięte z bezcennych tomów Romana Aftanazego oraz obszerne cytaty $\mathrm{z}$ dawniejszych wspomnień i literatury pięknej (Sienkiewicz!). Niemal wszystkie nieistniejące dziś siedziby posiadały oczywiście ongiś cenne zbiory, zniszczone lub rozproszone, którym autorzy relacji poświęcają nieco uwagi”29. Wiele „dźwiganych z ruin” kościołów zostało już odbudowanych, Romana Aftanazego zastąpił Grzegorz Rąkowski, pozostałe składniki recepty najwyraźniej nadal obowiązują.

${ }^{28}$ Historia Polski w liczbach. Ludność, terytorium, red. F. Kubiczek, Warszawa 1994, s. 14.

${ }^{29}$ J. Tazbir, Pokuszenie historyczne. Ze świata szabel i kontuszy, Łomża 2011, s. 41. 


\section{Bibliografia}

\section{Prasa:}

„Gazeta Lwowska” 1943.

„Kurier Lwowski” 1900.

„Przegląd Tygodniowy Życia Społecznego, Literatury i Sztuk Pięknych” 1876.

\section{Opracowania:}

Bayger A. J., Powiat trembowelski, Lwów 1899.

Biriulow J., Rzeźba lwowska od połowy XVIII wieku do 1939 roku, Warszawa 2007.

Czarnowski J., Perły Kresów, Warszawa 2010.

Historia Polski w liczbach. Ludność, terytorium, red. F. Kubiczek, Warszawa 1994.

Klimecki M., Wojna polsko-ukraińska. Lwów i Galicja Wschodnia 1918-1919, Warszawa 2000.

Łoza S., Gorgolewski Zygmunt, [w:] Polski słownik biograficzny, t. 8, Wrocław-Warszawa-Kraków 1959-1960, s. 316.

Mazur G., Skwara J., Węgierski J., Kronika 2350 dni wojny i okupacji Lwowa 1 IX 1939 - 5 II 1946, Katowice 2007.

Nicieja S. S., Cmentarz Obrońców Lwowa, Wrocław-Warszawa-Kraków 1990.

Pomniki epigrafiki i heraldyki dawnej Rzeczypospolitej na Ukrainie, red. W. Drelicharz, t. 1: Ziemia lwowska dawnego województwa ruskiego, oprac. A. Biedrzycka, Kraków 2005; t. 2: Dawne województwo podolskie, oprac. P. Kuliszewicz, Kraków 2005; t. 3: Ziemia przemyska dawnego województwa ruskiego, oprac. A. Marzec, Kraków 2008.

Osip-Pokrywka M. i M., Kresy, Warszawa 2013.

Osip-Pokrywka M. i M., Leksykon zabytków architektury Kresów południowo-wschodnich, Warszawa 2014.

Osip-Pokrywka M. i M., Sentymentalna Ukraina, Warszawa 2011.

Rąkowski G., Przewodnik po Ukrainie Zachodniej, cz. 2: Podole, Pruszków 2006; cz. 3: Ziemia lwowska, Pruszków 2007.

Seliga S., Pasiecznik. Parafraza IV. ks. Georgik Wergilego dokonana przez Gabrjela Świrskiego (w wieku XVI), „Prace Filologiczne” 1928, t. 9, s. 244-277.

Skrabski J., Kościół p.w. św. Wincentego Ferreriusza i klasztor oo. Dominikanów z przynależnymi zabudowaniami w Tarnopolu, [w:] Materiały do dziejów sztuki sakralnej na ziemiach wschodnich dawnej Rzeczypospolitej, cz. 1: Kościoły i klasztory rzymskokatolickie dawnego województwa ruskiego, t. 16, red. J. K. Ostrowski, Kraków 2008.

Smoliński A., „Bez ognia i miecza”. Migawki z sentymentalnych podróży po niepodległej Ukrainie w poszukiwaniu śladów byłej Rzeczypospolitej Obojga Narodów, „Semper Fidelis” 2008, nr 5, s. 5-11.

Strojny A., Bzowski K., Grossman A., Ukraina zachodnia. Tam szum Prutu, Czeremoszu..., Kraków 2011.

Szetelnicki W., Trembowla. Kresowy bastion wiary i polskości, Wrocław 1992.

Szklarz W., Pomnik św. Jana Nepomucena obok drogi Buczacz-Podzameczek, „Głos Buczaczan" R. 17, 2008, nr 2, s. 47.

Tazbir J., Pokuszenie historyczne. Ze świata szabel i kontuszy, Łomża 2011.

Urzędnicy województw kijowskiego i czernihowskiego XV-XVIII wieku. Spisy, oprac. E. Janas i W. Kłaczewski, Kórnik 2002. 
Walczy Ł., Dzieje wielkiego błędu. Ewolucja poglądów na początki Lwowa, „Cracovia-Leopolis" 2001, nr 1, s. 3-6.

Walczy Ł., Początki Lwowa w świetle najnowszych badań, „Sprawozdania z Posiedzeń Komisji Naukowej PAN. Oddział w Krakowie" 1998, t. 42/1, s. 138-143.

Walczy Ł., Początki Lwowa w świetle najnowszych badań, „Cracovia-Leopolis” 2004, nr 2, s. 8-11.

Walczy Ł., W sprawie początków Lwowa, [w:] Lwów. Miasto, społeczeństwo, kultura, t. 4, red. K. Karolczak, Kraków 2002, s. 31-37.

Żyła W., Kościół OO. Dominikanów w Tarnopolu 1749-1779, Lwów 1917.

Бірюльов Ю., Захаревичі. Твориі столичного Львова, Львів 2010.

Петегирич В., Найдавніше слов'янське житло зі Львова, „Галицька брама” 1996, nr 12, s. 3.

Петегирич В., Bстуn, [w:] Історія Львова, red. Я. Ісаєвич, т. 1: 1256-1772, Львів 2006, s. 30-37. 